\title{
INCIDENCE AND FACTORS RELATED TO THE APPEARANCE OF PRESSURE INJURIES IN AN INTENSIVE CARE UNIT
}

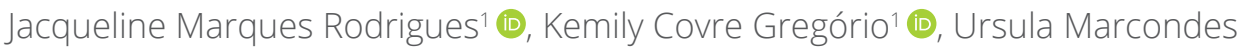 \\ Westin $^{1}$ (D), Danielle Garbuio ${ }^{1, *}$ (D)
}

\begin{abstract}
Objectives: identify the incidence and characterize pressure injuries in an adult intensive care unit regarding the occurrence, locations and risk factors, and verify whether there is an association between these and the appearance of the injuries. Method: observational, cohort, prospective study, developed in an intensive care unit of a tertiary hospital, from October to December 2019. The population consists of adults on the first day of admission to the unit, without pressure injury at admission. Participants were monitored during hospitalization, sociodemographic and clinical variables, and risk assessment of developing a pressure injury, skin assessment and Braden scale were collected daily. Pearson's chi-square tests and student's t-test were used to assessing the relationship between variables and injuries. For the analyzes, a significance level (a) of 5\% was considered. Results: 40 participants were included, $20 \%$ had pressure injuries with a predominance of stages 1 and 2; the main affected sites were the sacral region followed by the calcaneus. The average hospital stay was 23.38 days for the injured group and 5.77 days for the non-injured group; time showed a significant relationship with the appearance of lesions $(p=0.002)$. Conclusion: it was concluded that the most affected site was the sacral region and grade 1 was the most frequent staging; length of stay was the variable that influenced the appearance of injuries.
\end{abstract}

DESCRIPTORS: Nursing. Pressure injury. Risk factors. Intensive care units. Incidence. Stomatherapy.

\section{INCIDÊNCIA E FATORES RELACIONADOS AO APARECIMENTO DE LESÕES POR PRESSÃO EM UNIDADE DE TERAPIA INTENSIVA}

\section{RESUMO}

Objetivos: identificar a incidência e caracterizar as lesões por pressão em unidade de terapia intensiva adulta quanto à ocorrência, locais e fatores de risco, e verificar se há associação entre esses e o surgimento das lesões. Método: estudo observacional, coorte, prospectivo, desenvolvido em unidade de terapia intensiva de hospital terciário, de outubro a dezembro de 2019. A população constitui-se de adultos em primeiro dia de internação na unidade, sem lesão por pressão na admissão. Os participantes foram acompanhados durante a internação e variáveis sociodemográficas e clínicas, assim como avaliação do risco de desenvolver lesão por pressão, avaliação da pele e escala de Braden foram coletadas diariamente. Empregaram-se testes de Qui-quadrado de Pearson e teste $t$ de student para avaliar as relações entre variáveis e lesões. Para as análises foi considerado nível de significância (a) de 5\%. Resultados: foram incluídos 40 participantes, 20\% apresentaram lesão por pressão com predominância dos estágios 1 e 2; os principais locais afetados foram a região sacral seguida pelo calcâneo. 0 tempo médio de internação foi 23,38 dias para o grupo com lesão e 5,77 dias para o grupo sem lesão; o tempo

1. Centro Universitário Central Paulista - Faculdade de Enfermagem - São Carlos (SP), Brazil.

*Correspondence author: dgarbuio@yahoo.com.br

Section Editor: Juliano Teixeira Moraes

Received: Jan. 20, 2021| Accepted: Month. Mar. 31, 2021

How to cite: Rodrigues JM; Gregório KC; Westin UM; Garbuio D. Incidence and factors related to the appearance of pressure injuries in an intensive care unit. ESTIMA, Braz. J. Enterostomal Ther., 2021, 19: e1121. https://doi.org/10.30886/estima. v19.1014_IN 
apresentou relação significativa com o surgimento das lesões ( $p=0,002)$. Conclusão: conclui-se que o local mais acometido foi a região sacral e grau 1 o estadiamento mais frequente; o tempo de internação foi a variável que influenciou o surgimento de lesões.

DESCRITORES: Enfermagem. Lesão por pressão. Fatores de risco. Unidades de terapia intensiva. Incidência. Estomaterapia.

\title{
INCIDENCIA Y FACTORES RELACIONADOS CON LA APARICIÓN DE LESIONES POR PRESIÓN EN UNIDAD DE CUIDADOS INTENSIVOS
}

\begin{abstract}
RESUMEN
Objetivos: identificar la incidencia y caracterizar las lesiones por presión en una unidad de cuidados intensivos de adultos en cuanto a incidencia, localización y factores de riesgo y verificar si existe asociación entre estos factores y la aparición de lesiones. Método: estudio observacional, prospectivo, desarrollado en una unidad de cuidados intensivos de un hospital terciario de octubre a diciembre de 2019. La población está formada por adultos en primer día de ingreso en una unidad de cuidados intensivos, mayores de 18 años, sin lesiones por presión al ingreso. Los participantes fueron monitoreados durante toda su estadía hospitalaria y diariamente se recolectaron variables relacionadas con evolución clínica, evaluación de la piel y escala de Braden. Se utilizaron las pruebas de chi-cuadrado de Pearson y t de Student para evaluar las asociaciones, considerando nivel de significancia de 5\%. Resultados: se incluyeron 40 participantes, de los cuales el 20\% presentaba lesiones por presión, con predominio de los grados 1 (33,3\%) y 2 (33,3\%); los principales sitios afectados fueron la región sacra (77,7\%), seguida del calcáneo (11,1\%). La estancia hospitalaria promedio fue de 23,38 días para el grupo que presentó lesión y 5,77 días para el grupo sin lesión y presentó una relación significativa con la aparición de las lesiones $(p=0,002)$. Conclusiones: Se concluyó que el sitio más afectado fue la región sacra y el grado 1 fue la estadificación más frecuente; la duración de la estancia fue la única variable que influyó en la aparición de lesiones.
\end{abstract}

DESCRIPTORES: Enfermería; Lesión por presión; Factores de riesgo; Unidades de cuidados intensivos, Incidencia.

\section{INTRODUCTION}

A hospitalization is a remarkable event for the patient and his family, not only because of the pathology in question but also because of all the risks permeating this period. Fragility, the need for intensive care, the performance of invasive procedures and the use of accessory devices are some of the factors that increase this exposure, especially for events related to skin tissue.

Nursing in its field of action should aim to provide quality care, seeking to reduce possible risks. Among these, the risk of damage to the integrity of the skin can result in injuries, with pressure injuries (PI) being more common.

The National Pressure Injury Advisory Panel (NPIAP) defines this injury as damage restricted to the skin and its underlying tissues, being usually present on a bony prominence or even related to the use of medical devices or artifacts. These lesions appear on intact skin or lesions and result from intense, prolonged pressure combined with friction and shear ${ }^{1}$.

They are considered a socioeconomic problem, and their appearance can have a significant financial impact on the institution and the quality of life of the patient and their family ${ }^{2}$ Among the numerous problems that PI can cause, the following stand out: prolonged hospitalization, greater difficulty in recovering the patient, risk of developing other complications, in addition to greater morbidity and mortality of affected patients, which directly reflects in the costs for services health care and family economics of inpatients ${ }^{3-5}$. As a result, the search for care and means to prevent its onset and the risk factors have been the target of research for a long time ${ }^{3,6,7}$.

National studies indicate that the incidence of PI can vary between 6 and $62 \%$ depending on the service and sectors evaluated, with the Intensive Care Unit (ICU) being the sector with the most significant number of these injuries. In 
addition, the most affected are people over 42 years old, men, white, with a hospital stay longer than 9 days. The location and staging of these lesions are also variable in the literature, being more frequent in the sacral and calcaneus regions, with stages 1 and $2^{8-12}$.

The international literature, in turn, points out an incidence between $5.1 \%$ and $12.8 \%$ in different hospital settings ${ }^{13-16}$, the most frequent stages being 1 and 2, and the most incident locations were the sacral region and those related to the use of a medical device ${ }^{13,14,16}$. One study, however, pointed out that the most common stages were unclassified and deep tissue damage ${ }^{16}$.

Several conditions can be considered at risk for PI, including pressure, which causes decreased perfusion and oxygenation, nutritional status, excess moisture in the skin, increased body temperature, advanced age, sensory perception, mobility and activity restriction, hematological status and general health status ${ }^{1,6,7}$. The NPIAP also points out, as additional risk factors, fragile skin, the presence of pre-existing lesions even if healed, the circulatory damage in the extremities due to vascular disease, diabetes or tobacco use ${ }^{1}$.

It is also noteworthy the vulnerability of patients admitted to the ICU. They are more likely to develop PI since they are often under the effect of vasoactive drugs, sedation and mechanical ventilation, with mobility restricted to the bed and impaired skin integrity ${ }^{17,18}$.

Given the role of the nursing team in the assessment of this population and the implementation of prevention activities, it is essential to monitor the risk to which each patient is subjected ${ }^{1}$. Early identification of the population at risk allows for rapid planning and implementation of preventive actions ${ }^{19}$. Furthermore, studies for evaluating the incidence indicators and characteristics of PI contribute to the evaluation of institutional protocols for the prevention of these injuries ${ }^{14}$.

Thus, the identification of the incidence and the characterization of PI and the factors associated with its appearance can contribute to the evaluation of the quality indicators of care and the development of a care plan aimed at reducing the incidence through the identification of risk factors, improving the quality of care and reducing, as a consequence, length of stay and costs of care. The objective of this study was to identify the incidence and characterize the PI in an adult ICU as to the occurrence, locations and risk factors and to verify whether there is an association between these factors and the appearance of these lesions.

\section{METHOD}

This is a quantitative, observational, cohort, prospective study developed from October to December 2020.

It was developed in a general adult ICU of a philanthropic tertiary hospital in a city in the interior of São Paulo. This unit has ten beds and serves surgical and clinical patients, except for cardiologists assigned to the specific unit. It has a protocol for preventing PI and uses the Braden scale as a risk predictor.

The study population consisted of men and women on the first day of admission to the ICU. To participate in the survey, participants met the following inclusion criteria: being over 18, being in the first 24 hours of admission to the ICU, and do not present PI at the time of admission. The exclusion criterion was to stay in the ICU for less than 24 hours due to death or discharge. The risk of developing PI was assessed, but it was not considered a criterion for inclusion in the study.

Data collection was carried out by two previously trained researchers, who daily obtained the clinical information from the medical records in the unit and screening and evaluating the eligibility for inclusion of the participants. The nursing team performed the skin assessment at the time of each patient's hygiene, and the researchers accessed the information (presence of PI, stage and location) in the records. Nursing professionals in the sector have periodic training on the subject.

The participants who presented the study's eligibility criteria were invited to participate, by the researchers, at the time of admission to the intensive care sector; if this is not possible, the invitation was made to a family member or legal guardian. The patient or family member was informed about the objectives, risks and benefits of the study and, in case of acceptance, signed the Free and Informed Consent Term (ICF) in two copies. 
After acceptance, the researchers filled out the data collection instrument composed of sociodemographic information: age, sex, race; clinical data: smoking and drinking habits, vital signs, use of mechanical ventilation, vasoactive drugs, sedation, feeding, urinary elimination, length of stay and laboratory tests (hemoglobin, platelets, leukocytes, lactate, C-reactive protein, International Normalized Ratio - INR, blood glucose); and assessment of the risk of PI using the Braden scale7. The instrument was developed for the sole purposes of this study and was sent to three evaluators before being used in the research to assess the content, clarity and relevance.

Participants were monitored throughout their stay in the ICU, and assessments related to clinical and laboratory tests, clinical evolution and skin evaluation were performed daily. The records of laboratory tests were collected from the electronic medical record, and skin evaluations were performed by nurses in the sector, considering integrity (presence or absence of PI), stage and location of the lesion, when present. It is noteworthy that the team receives periodic training on the subject and integumentary assessment.

Initially, the recorded data were distributed in tables and analyzed using descriptive statistics. Later, for the analysis of the relationship of the categorical variables, Pearson's chi-square test was used and for the quantitative ones, the student t-test for independent samples, using IBM SPSS Statistics $22^{\circledR}$ software. The level of significance $(\alpha)$ of $5 \%$ and power of $80 \%$ was considered for the analyzes. The incidence of PI was calculated by dividing the number of participants with PI by the total number of participants ${ }^{20}$. For the classification of the stages of PI, the one described by the NPIAP was used ${ }^{15}$. For the variables of vital signs and clinical examinations, an average of the daily measurements per participant was initially calculated and, subsequently, the general average of the group.

This work was approved by the Human Research Ethics Committee of the Centro Universitário Central Paulista (opinion number 3,598,407 / 2019). For its development, the recommendations in Resolution 466/2012 of the National Health Council were observed ${ }^{21}$, which aims to protect research participants, and the participant or his family member was informed and was able to request a withdrawal at any time.

Initially, 48 participants were screened to participate in the research, and the flow of inclusion and screening is described in Fig. 1.

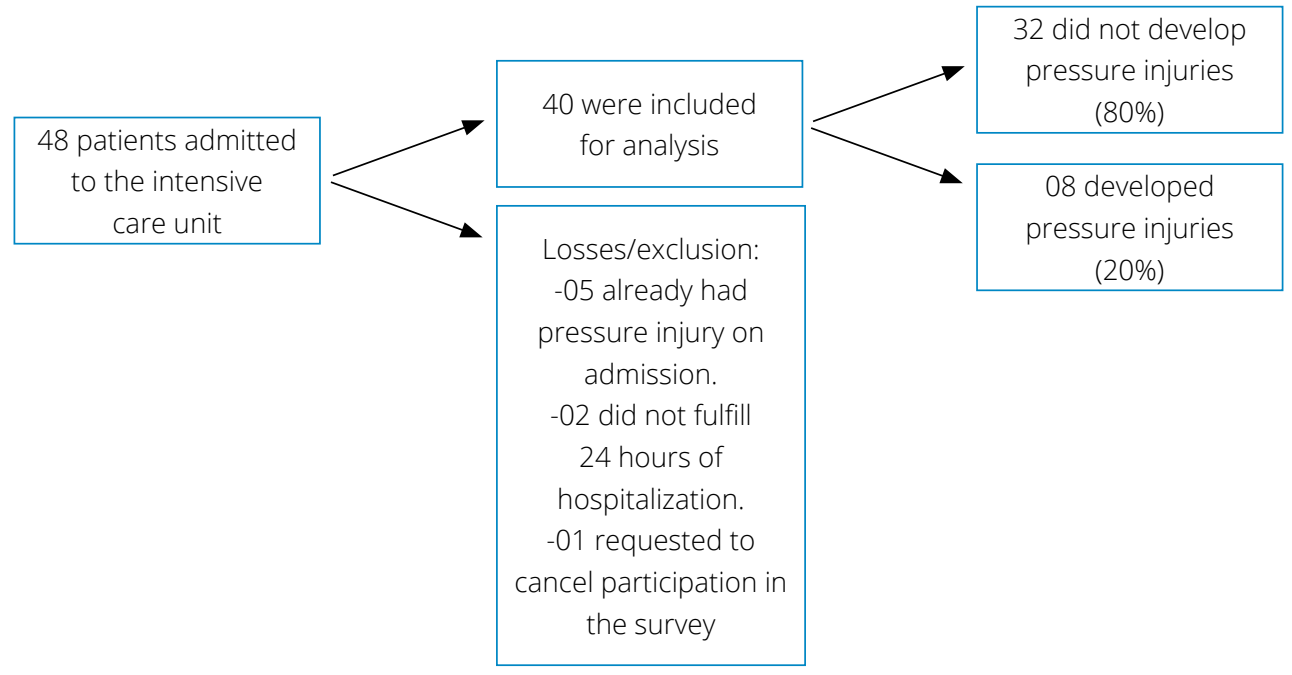

Figure 1. Flowchart of screening and inclusion of participants in the research. São Carlos (SP), Brasil - 2020.

\section{RESULTS}

Of the 40 participants included in the survey, 19 (47.5\%) were older than 60 years, $23(57.5 \%)$ were men and 17 (42.5\%) women; in relation to race, 23 (57.5\%) were white, 13 (32.5\%) were brown, and 3 (7.5\%) were black; as for marital status, there was an equality in values with $16(40 \%)$ married and 16 (40\%) single, with the other $20 \%$ being divided into 
widowers, divorced and in a stable relationship. Regarding the main diagnosis at the time of admission, most participants were diagnosed with cerebrovascular disorders (28.2\%), followed by patients in the immediate postoperative period of several surgeries (25.6) and polytrauma (12.8\%).

An incidence of $20 \%$ of PI $(n=8)$ was identified in the sample studied. The principal site affected was the sacral region (77.7\%), followed by the calcaneus (11.1\%) and gluteus (11.1\%). As for staging, lesions were predominant in stage 1 (33.3\%) and 2 (33.3\%), followed by lesions in stage $4(22.2 \%)$ and $3(11.1 \%)$. No lesions without staging or deep tissue damage were identified in the sample. Only 1 participant (2.5\%) presented 2 PI during hospitalization, one in the sacral region and the other in the calcaneus. There were no participants with 3 or more PI in the sample and period studied.

One participant (2.5\%) had an evolution in the lesion stage, with the initial PI in the sacral region stage 1 that evolved to stage 4 on its 29th day of hospitalization. This same patient presented another lesion in the calcaneus region in stage 1, which evolved to stage 4 on his 26 th day of hospitalization. For the percentage calculations of each stage, the two measures of this participant were considered.

As for the variables and their relationship with the development of PI, Table 1 presents the description of the sociodemographic variables and life habits of patients with and without PI. In this analysis, no significant relationship between the variables and the development of PI was found. However, it is possible to identify differences in the percentage number between the variables of patients with injury and patients without injury.

Table 1. Description and analysis of sociodemographic variables and lifestyle in patients with and without pressure injuries $(n=40)$. São Carlos (SP), Brasil - 2019.

\begin{tabular}{|c|c|c|c|}
\hline Variables & $\begin{array}{c}\text { With injury } \\
\mathrm{n}(\%)\end{array}$ & $\begin{array}{c}\text { Without injury } \\
\mathrm{n}(\%)\end{array}$ & p-value* \\
\hline \multicolumn{4}{|l|}{ Gender } \\
\hline Female & 03 (37.5) & $13(43.75)$ & \multirow{2}{*}{0.052} \\
\hline Male & 05 (62.5) & $18(56.25)$ & \\
\hline \multicolumn{4}{|l|}{ Race } \\
\hline White & 07 (87.5) & $15(50)$ & \multirow{3}{*}{0.155} \\
\hline Brown & $01(12.5)$ & $12(37.5)$ & \\
\hline Black & $0(0.0)$ & 03 (9.3) & \\
\hline \multicolumn{4}{|l|}{ Smoking } \\
\hline Yes & $02(25.0)$ & 07 (21.8) & \multirow{3}{*}{0.563} \\
\hline No & $01(12.5)$ & $06(21.8)$ & \\
\hline Ex-smoker & $01(12.5)$ & $01(3.1)$ & \\
\hline \multicolumn{4}{|l|}{ Alcoholism } \\
\hline Yes & $01(12.5)$ & $03(9.3)$ & \multirow{2}{*}{0.658} \\
\hline No & $01(12.5)$ & $06(21.8)$ & \\
\hline
\end{tabular}

*Pearson's Chi-square test

Concerning clinical variables and their relationship with the development of PI, length of stay was the only variable that showed a significant relationship with the development of these lesions $(p=0.002)$. It is noted that the mean values of hemoglobin and platelets are lower in the group with injury when compared to the group without injury. The average values of $\mathrm{C}$-reactive protein (CRP) found are higher in the group with injury when compared to the group without injury (Table 2). 
Table 2. Table 2.Description of the mean, standard deviation and analysis of the relationship of the variables measured in patients with and without pressure injury $(n=40)$. São Carlos (SP), Brasil

\begin{tabular}{|c|c|c|c|c|c|}
\hline \multirow{2}{*}{ Variables } & \multicolumn{2}{|c|}{ With injury } & \multicolumn{2}{|c|}{ Without injury } & \multirow{2}{*}{ p-value* } \\
\hline & Mean & Standard deviation & Mean & Standard deviation & \\
\hline Age & 64.25 & 13.275 & 57.42 & 21.503 & 0.276 \\
\hline Length of hospital stay & 23.38 & 10.967 & 5.77 & 4.364 & $0.002 \dagger$ \\
\hline \multicolumn{6}{|l|}{ Vital signs } \\
\hline Heart rate & 86.84 & 10.785 & 85.10 & 17.606 & 0.792 \\
\hline Temperature & 36.43 & 0.600 & 36.33 & 0.476 & 0.616 \\
\hline Respiratory frequency & 19.41 & 1.775 & 17.52 & 3.218 & 0.119 \\
\hline Systolic blood pressure & 125.54 & 9.290 & 122.60 & 13.826 & 0.574 \\
\hline Diastolic blood pressure & 71.77 & 9.492 & 70.22 & 8.583 & 0.657 \\
\hline \multicolumn{6}{|l|}{ Laboratory tests } \\
\hline Hemoglobin & 9.57 & 1.193 & 10.08 & 1.921 & 0.366 \\
\hline Platelets & $196,716.84$ & 86701.789 & $212,701.66$ & 97555.790 & 0.678 \\
\hline Leukocytes & 14.014 .78 & 3034.252 & 15.267.17 & 12065.689 & 0.775 \\
\hline Lactate & 2.11 & 0.649 & 1.87 & 0.895 & 0.492 \\
\hline C-reactive protein & 18.03 & 10.043 & 15.35 & 11.309 & 0.554 \\
\hline INR & 1.58 & 0.655 & 1.31 & 0.478 & 0.322 \\
\hline Glucose & 146.24 & 25.979 & 139.96 & 53.908 & 0.754 \\
\hline
\end{tabular}

*Student's t test; $\uparrow p<0,05 ;$ INR = International Normalized Ratio

Regarding the other clinical variables analyzed, it was observed that there was no significant relationship with the development of the lesions. Although some variables have a higher percentage in the group with injury compared to the group without injury, none of them were significant concerning the appearance of injuries (Table 3).

Table 3. According to their distribution in participants with injury and without pressure injury ( $\mathrm{n}=40$ ), presentations of clinical variables are presented. São Carlos (SP), Brasil - 2019.

\begin{tabular}{|c|c|c|c|}
\hline Variables & $\begin{array}{c}\text { With injury } \\
\mathrm{n}(\%)\end{array}$ & $\begin{array}{c}\text { Without injury } \\
n(\%)\end{array}$ & p-value* \\
\hline \multicolumn{4}{|c|}{ Mechanical ventilation } \\
\hline Yes & $5(62.5)$ & $13(43.75)$ & \multirow{2}{*}{0.376} \\
\hline No & $3(37.5)$ & $16(50)$ & \\
\hline \multicolumn{4}{|c|}{ Vasoactive Drugs } \\
\hline Yes & $5(62.5)$ & $10(31.25)$ & \multirow{2}{*}{0.068} \\
\hline No & $1(12.5)$ & $14(43.75)$ & \\
\hline \multicolumn{4}{|l|}{ Sedation } \\
\hline Yes & $4(50)$ & $11(34.3)$ & \multirow{2}{*}{0.280} \\
\hline No & $4(50)$ & $13(40.6)$ & \\
\hline \multicolumn{4}{|l|}{ Feeding } \\
\hline NGT/NET & $6(75)$ & $10(31.2)$ & \multirow{4}{*}{0.383} \\
\hline Oral & $2(25)$ & $8(25)$ & \\
\hline Fast & $0(0)$ & $4(12.5)$ & \\
\hline Gastrostomy & $0(0)$ & $1(3.1)$ & \\
\hline \multicolumn{4}{|c|}{ Urinary Elimination } \\
\hline IBC & $5(62.5)$ & $22(71.8)$ & \multirow{3}{*}{0.372} \\
\hline Diaper & $1(12.5)$ & $1(3.1)$ & \\
\hline Continent & $0(0)$ & $3(9.3)$ & \\
\hline
\end{tabular}

*Pearson's Chi-square test; NGT =Nasogastric tube; NET = Nasoenteric tube; IBC = Indwelling bladder catheter. 
When observing the values assigned in the risk assessment for the development of PI using the Braden scale in participants with and without injury, it is noted that no patient without injury had a very high risk (6-9). Most of the injured group had a percentage of $62.5 \%$ for high risk (10-12), $25 \%$ for moderate risk (13-14), $12.5 \%$ for low risk (15-18) and no patient had a risk score greater than or equal to 19 (Table 4).

Table 4. Distribution of the Braden scale score according to risk in participants with and without injury. São Carlos (SP), Brasil - 2020.

\begin{tabular}{lccc}
\hline Injury & $\begin{array}{c}\text { High risk } \\
(10-12) \\
\mathbf{n}(\%)\end{array}$ & $\begin{array}{c}\text { Moderate Risk } \\
(13-14) \\
\mathbf{n}(\%)\end{array}$ & $\begin{array}{c}\text { Low Risk } \\
(\mathbf{1 5 - 1 8 )} \\
\mathbf{n}(\%)\end{array}$ \\
\hline Without & $10(33.3)$ & $12(40)$ & $8(26.7)$ \\
\hline With & $15(62.5)$ & $14(25)$ & $9(12.5)$ \\
\hline
\end{tabular}

\section{DISCUSSION}

The incidence of PI found in this study was $20 \%$, with a length of stay as a variable with a statistically significant difference ( $p=0.002)$ related to its onset. Most patients developed only one lesion, most of which were located in the sacral region, with grade 1 and grade 2 staging.

It is observed that the results of this study about the incidence of PI in ICU patients corroborate a study carried out with critically ill patients, in which the incidence of these injuries was $22 \%$, with a predominance of lesions in the sacral region (47\%), also classified as grade $1(72 \%)^{12}$. Another study carried out in the ICU ${ }^{22}$ presented an incidence of $10.47 \%$ of PI with predominance in the sacral region (46.4\%), classified as grade 2 (61.9\%).

In agreement with this information, the study by Constantin and collaborators ${ }^{8}$ pointed out an incidence of $20.6 \%$ of these injuries, $76.5 \%$ of which in the sacral region and $58.9 \%$ in stage 2 . Furthermore, a study developed in intensive care units specialized in oncology found similar incidence $(29.5 \%)$ and place of involvement (81\% in the sacral region $)^{18}$.

A systematic review of the prevalence of PI in the world showed a global value of $12.8 \%$ in hospitalized patients. The locations with the highest prevalence of these injuries were Europe (14.5\%), followed by North America (13.6\%) and South America (12.7\%). This study also pointed out that the highest prevalence was concentrated in stages 1 and $2(43.5 \%)^{13}$. It is observed that the global indexes are lower than those found in this study and the other national studies $^{8,12,14,16}$.

Concerning staging, this study did not find lesions at an undetermined stage or deep tissue injury, which differs from the study by Sala et al. ${ }^{16}$, in which the highest percentages of PI were from these injuries, with $33.3 \%$ unclassified, $31.8 \%$ deep tissue injury and only $10.5 \%$ in stage 2 .

Regarding gender, there was a higher occurrence of PI in males (63.5\%) in the sample studied, but it did not present a significant relationship with the appearance of lesions $(p=0.052)$. Similar findings were found in a study carried out in the Brazilian Midwest, which showed a PI occurrence of 52.9\% in males in their results ${ }^{23}$. Other studies also point out the predominance of males in the incidence of PI, without, however, having a significant relation ${ }^{10-12,24}$. On the other hand, a study carried out in a cardiothoracic intensive care unit showed an incidence of $8.0 \%$ of PI in men and $3.0 \%$ in women, showing a significant association $(\mathrm{p}=0.018)$ between males and the appearance of $\mathrm{PI}^{9}$.

As for the race, it was observed in this study that $87.5 \%$ of the white population developed PI, and only $12.5 \%$ of the brown population had PI. In comparison with a Brazilian study, it is noted that the results were similar, and $82 \%$ of the patients who developed PI were white and only $18 \%$ of the non-white population ${ }^{12}$. However, Mendonça and collaborators ${ }^{23}$ pointed out that $70.6 \%$ of the patients who developed PI were not white, and $29.4 \%$ were white. It is important to note that PI grade 1 can be challenging to identify in people with non-white skin ${ }^{25}$. 
Smoking in this study had no significant relationship with the onset of PI $(\mathrm{p}=0.563)$. This result agrees with a study that found $82 \%$ of non-smokers and $18 \%$ of smokers in the population with PI and did not present a significant relation ${ }^{12}$. Still, the study by Matozinhos and collaborators ${ }^{24}$, a prospective cohort to estimate the incidence rate of PI in hospitalized patients at the medical clinic and verify the associated factors, also found no significant association between smoking and the development of these lesions.

Regarding alcoholism, the data found in this study inform that there was no correlation between the results and the appearance of PI. This data corroborates what was observed in another study in a hospital in the Serra Gaúcha, that only $5.1 \%$ of the patients who developed PI were alcoholics. ${ }^{26}$

The average age in patients with injury was 64.25 years; the finding was similar to the result of a study carried out in an oncology ICU, in which the average age of the participants was 56.7 years (SD: 15.6), and of those who had PI, 45.2\% had more 60 years $^{18}$.

In the present study, age had no significant relationship with the onset of PI. However, a case-control study developed in the ICU found a significant relationship for the onset of this lesion at age over 61 years.10 Aging causes several bodily changes, such as reduced natural hydration and altered collagen synthesis, which makes the tissues more rigid, reducing the pressure distribution capacity and, as a consequence, greater impairment of local circulation and, with this, greater risk of developing $\mathrm{PI}^{27}$.

The length of hospital stay was the only variable with a significant relationship to the appearance of PI in this study ( $\mathrm{p}=0.002)$, with an average of 23.38 days of hospitalization for patients with injury. The literature describes a study that agrees with this finding, pointing out as significant the relationship between the onset of PI and the length of hospital stay greater than 30 days $^{10}$.

Within the variables of vital signs, there was no significant relationship with the appearance of lesions. However, in a national study, the authors found that hyperthermia presented a statistically significant association in relation to the occurrence of $\mathrm{PI}^{23}$. It is known that the increase in body temperature accelerates tissue metabolism and, thus, the demand for oxygen, which may be related to tissue devitalization and increased risk of necrotic tissue in the lesion. ${ }^{27}$

In relation to laboratory tests, in this study, the mean hemoglobin values in the group with injury were 9.57 and, although lower than in the group without injury, they did not show a significant relationship for the development of the lesions ( $p=0.366)$. However, in the literature, a higher percentage of altered hemoglobin values (94.1\%) was identified in patients with $\mathrm{PI}^{23}$. Leukocytes, in this study, also did not have a significant relationship with the appearance of PI $(p=0.775)$. However, the study mentioned above also describes a higher percentage of altered leukocytes in patients who developed PI $(60.8 \%)^{23}$.

Considering the evaluation of laboratory tests in the development of PI, the NPIAP points out that there is no solid evidence that associates values of laboratory tests with a greater risk of developing $\mathrm{PI}^{1}$.

Mechanical ventilation was present in $62.5 \%$ of the patients who developed a lesion. However, this value did not show a statistically significant relationship with the appearance of the lesions. A similar finding points out that mechanical ventilation did not show a higher risk of developing PI than spontaneous ventilation ${ }^{23}$. Such data diverge from a study that found mechanical ventilation as an important risk factor for the development of PI. ${ }^{17}$

As for sedation, the results had no significant relationship with the appearance of the lesions $(p=0.280)$. The data corroborates a Brazilian study in which there was no significant relationship between this variable and the emergence of PI $(\mathrm{p}=0,699)^{12}$.

Regarding the use of vasoactive drugs, there was no significant relationship with the appearance of lesions, even though the percentage of patients using vasoactive drugs was higher in the group with injury than the group without injury. This relationship was not found in the literature either; a study pointed out that the use of vasoactive drugs in the group with lesions was $58.8 \%$ and did not represent a significant relationship with the appearance of lesions $(\mathrm{p}=0,246)^{23}$.

In contrast, a study developed in intensive cancer therapy found a significant relationship between the use of vasoactive drugs and sedation with the emergence of $\mathrm{PI}^{18}$. Literature findings show that prolonged administration 
of vasoactive drugs and sedation require bed rest, which contributes to immobility and causes important peripheral vasoconstriction, which may predispose to the appearance of lesions ${ }^{18,27}$.

Regarding food, in this study, patients in the injured group made greater use of a nasogastric tube (NGT)/nasoenteric tube (NET) (75\%) followed by oral feeding (25\%) and did not present patients with fasting or gastrostomy, being that none of these situations had a significant relationship with the appearance of the lesions. However, Jomar and collaborators ${ }^{18}$ describe a significant relationship between enteral feeding, the presence of diarrhea and nutritional conditions as significant risk factors for the development of PI. The literature points out that adequate nutrition is important to assist in the healing stages and prevent the development of $\mathrm{PI}^{27}$.

Concerning urinary elimination, a Brazilian study pointed out that $92.2 \%$ of patients with lesions were continents or were using an indwelling bladder catheter (IBC), and 7.8\% were incontinent, using diapers, having no significant relationship with the appearance of injuries ${ }^{23}$. These data agree with the present study. The literature points out. However, skin damage resulting from moisture can occur, which is a significant risk factor for $\mathrm{PI}^{1,27}$.

\section{CONCLUSION}

The incidence of PI in the evaluated patients was $20 \%$, and the length of stay was the only variable with a statistically significant relationship for the appearance of the lesions. Comparing with the other studies, it is noted that the results showed much variation with the risk factors, which suggests the need for further research.

Based on this study, it can be seen that patients who remained hospitalized for an extended period developed PI. Thus it is possible to understand that care for the prevention of PI is essential during the entire hospitalization period. Thus, the role of nursing in this evaluation and implementation of care measures stands out.

As limitations, the study did not evaluate the extrinsic factors that could be related to the appearance of PI as well as the use of devices used in the prevention, such as specific mattresses and other care that may be related to the incidence of PI. Still, as a limitation, data on fecal incontinence was not collected, increasing local humidity and promoting the development of injuries.

As a future proposal, there is the use of Digital Information and Communication Technology (DICT) and the use of clinical simulation scenarios for the teaching and continuing education of professionals in the sector in relation to the identification of risk and care factors for this clientele, aiming at a continuous improvement in the quality of patient care. In addition, the incidence of PI is an indicator of patient safety and can be used to evaluate preventive measures and protocols for the continuous improvement of care.

\section{AUTHORS' CONTRIBUTION}

Conceptualization: Garbuio D; Methodology: Garbuio D; Research: Garbuio D, Rodrigues JM and Gregório KC; Writing - First version: Rodrigues JM and Gregório KC; Writing - Review \& Editing: Garbuio D and Westin UM; Funding acquisition: Garbuio D; Supervision: Garbuio D.

\section{DATA STATEMENT AVAILABILITY}

All data were generated and analyzed in the study.

\section{FUNDING}

Conselho Nacional de Desenvolvimento Científico e Tecnológico

https://doi.org/10.13039/501100003593 


\section{REFERENCES}

1. European Pressure Ulcer Advisory Panel, National Pressure Injury Advisory Panel and Pan Pacific Pressure Injury Alliance. Prevention and Treatment of Pressure Ulcers/Injuries: Quick Reference Guide. Emily Haesler (Ed.). EPUAP/NPIAP/PPPIA: 2019.

2. Andrade CCD, Almeida CFSC, Pereira WE, Alemão MM, Brandão CMR, Borges EL. Custos do tratamento tópico de pacientes com úlcera por pressão. Rev esc enferm USP 2016;50(2):295-301. http://doi.org/10.1590/S0080-623420160000200016

3. Fernandes LM, Caliri MHL, Haas VJ. Efeito de intervenções educativas no conhecimento dos profissionais de enfermagem sobre prevenção de úlceras por pressão. Acta Paul Enferm 2008;21(2):305-11. https://doi.org/10.1590/S0103-21002008000200012

4. Souza DMST, Santos VLCG. Incidence of pressure ulcers in the institutionalized elderly. J Wound Ostomy Continence Nurs 2010;37(3): 272-6. https://doi.org/10.1097/WON.0b013e3181d8c25c

5. Lanzoni GMM, Goularte AF, Koerich C, Reisdorfer E, Miotello M, Meirelles BHS. Eventos adversos e incidentes sem dano em unidades de internação de um hospital especializado em cardiologia. REME - Rev Min Enferm 2019;23:e-1184. http://doi. org/10.5935/1415-2762.20190032

6. Serpa LF, Santos VLCG, Campanili TCGF, Queiroz M. Validade preditiva da Escala de Braden para o risco de desenvolvimento de úlcera por pressão em pacientes críticos. Rev Latino-Am Enfermagem 2011; 19(1):1-8. https://doi.org/10.1590/S010411692011000100008

7. Paranhos WY, Santos VLCG. Avaliação de risco para úlceras de pressão por meio da Escala de Braden, na língua portuguesa. Rev Esc Enferm USP 1999;33(esp):191-206. Available at: https://pesquisa.bvsalud.org/portal/resource/pt/biblio-1025947

8. Constantin AG, Moreira APP, Oliveira JLC, Hofstätter LM, Fernandes LM. Incidência de lesão por pressão em unidade de terapia intensiva para adultos. ESTIMA Braz J Enterostomal Ther 2018; 16: e1118. https://doi.org/10.30886/estima.v16.454_PT

9. Campanili TCGF, Santos VLCG, Strazzieri-Pulido KC, Thomaz PBM, Nogueira PC. Incidência de úlceras por pressão em pacientes de Unidade de Terapia Intensiva Cardiopneumológica. Rev esc enferm USP 2015;49(esp):7-14. https://doi.org/10.1590/S0080623420150000700002

10. Pachá HHP, Faria JIL, Oliveira KA, Beccaria LM. Lesão por Pressão em Unidade de Terapia Intensiva: estudo de caso-controle. Rev Bras Enferm 2018;71(6):3203-10. https://doi.org/10.1590/0034-7167-2017-0950

11. Pereira AFM, Beserra WC, Pereira MCC, Andrade EMLR, Luz MHBA. Pressure injury incidence in a university hospital. Rev Enferm UFPI 2017;6(1):36-9. https://doi.org/10.26694/reufpi.v6i1.5771

12. Borghardt AT, Prado TN, Bicudo SDS, Castro DS, Bringuente MEO. Pressure ulcers in critically ill patients: incidence and associated factors. Rev Bras Enferm 2016;69(3):431-8. https://doi.org/10.1590/0034-7167.2016690307i

13. Li Z, Lin F, Thalib L, Chaboyer W. Global prevalence and incidence of pressure injuries in hospitalised adult patients: A systematic review and meta-analysis. Int J Nurs Stud 2020;105:103546. https://doi.org/10.1016/j.jpurstu.2020.103546

14. Díaz-Caro I, Gómez-Heras SG. Incidence of hospital-acquired pressure ulcers in patients with "minimal risk" according to the “Norton-MI" scale. PLoS ONE. 2020;15(1):e0227052. https://doi.org/10.1371/journal.pone.0227052

15. Alderden J, Drake KP, Wilson A, Dimas J, Cummins MR, Yap TL. Hospital acquired pressure injury prediction in surgical critical care patients. BMC Med Inform Decis Mak 2021; 21(1):12. https://doi.org/10.1186/s12911-020-01371-z

16. Sala JJ, Mayampurath A, Solmos S, Vonderheid SC, Banas M, D'Souza A et al. Predictors of pressure injury development in critically ill adults: A retrospective cohort study. Intensive Crit Care Nurs 2021;62:102924. https://doi.org/10.1016/j.iccn.2020.102924

17. Loudet $\mathrm{Cl}$, Marchena MC, Maradeo MR, Fernández SL, Romero MV, Valenzuela GE et al. Diminuição das úlceras por pressão em pacientes com ventilação mecânica aguda prolongada: um estudo quasi-experimental. Rev bras ter intensiva 2017;29(1):3946. Available at: https://www.scielo.br/scielo.php?pid=S0103-507X2017000100039\&script=sci_abstract\&tlng=pt

18. Jomar RT, Jesus RP, Jesus MP, Gouveia BR, Pinto EN, Pires AS. Incidência de lesão por pressão em unidade de terapia intensiva oncológica. Rev Bras Enferm 2019;72(6):1566-71. https://doi.org/10.1590/0034-7167-2018-0356

19. Zimmermann GS, Cremasco MF, Zanei SSV, Takahashi SM, Cohrs CR, Whitaker IY. Predição de risco de lesão por pressão em pacientes de unidade de terapia intensiva: revisão integrativa. Texto contexto - enferm 2018;27(3):e3250017. https://doi. org/10.1590/0104-07072018003250017

20. Polit DF, Beck CT. Essentials of nursing research: appraising evidence for nursing practice. 8a ed. Philadelphia (USA): Lippincott Williams \& Wilkins; 2014.

21. Resolução CNS n. 466, de 12 de dezembro de 2012. Dispões sobre as Diretrizes e Normas regulamentadoras de pesquisas envolvendo seres humanos. Diário Oficial da União [periódico na internet], Brasília (DF).

22. Teixeira AKS, Nascimento TS, Souza ITL, Sampaio LRL, Pinheiro ARM. Incidência de lesões por pressão em Unidade de Terapia Intensiva em hospital com acreditação. ESTIMA Braz J Enterostomal Ther 2017;15(3):152-60. https://doi.org/10.5327/Z18063144201700030006 
23. Mendonça PK, Loureiro MDR, Júnior MAF, Souza AS. Ocorrência e fatores de risco para lesões por pressão em centros de terapia intensiva. Rev enferm UFPE on line. 2018;12(2):303-11. https://doi.org/10.5205/1981-8963-v12i2a23251 p303-311-2018

24. Matozinhos FP, Velasquez-Melendez G, Tiensoli SD, Moreira AD, Gomes FSL. Factors associated with the incidence of pressure ulcer during hospital stay. Rev Esc Enferm USP 2017;51:e03223. http://doi.org/10.1590/S1980-220X2016015803223

25. Sales DO, Waters C. The use of the Braden Scale to prevent pressure injury in intensive care unit patients. Braz J Hea Rev 2019;2(6):4900-25. Available at: file:///C:/Users/user/Downloads/4300-16620-1-PB\%20(3).pdf

26. Candaten AE, Vieira YB, Barcellos RA. Incidência de lesões por pressão em pacientes internados em unidades de terapia intensiva. Rev. Uningá. 2019; 56(2):30-40. Available at: http://revista.uninga.br/index.php/uninga/article/view/1455

27. Geovanini T. Tratamentos e Cuidados específicos nas úlceras por pressão. In: Geovanini T. Tratado de feridas e curativos. São Paulo: Rideel, 2014. 